\title{
The Submersed Aquatic Plant Community in JaCkson Lake, Grand Teton National Park, WYOMING
}

\section{CAROL A. BREWER $\uparrow$ DIVISION OF BIOLOGICAL SCIENCES UNIVERSITY OF MONTANA $\uparrow$ MISSOULA}

\section{$\uparrow \quad$ INTRODUCTION}

Submergent macrophyte distribution in lakes is usually related to depth. At lower depths (downslope on the littoral lake bed), macrophyte distribution and growth have been related to light (Spence 1982), substrate texture, nutrient status (Carpenter and Adams 1977), and lake morphometry (Duarte and Kalff 1986). Factors limiting distribution and growth at shallower depths (upslope on the littoral shore) are not as well understood.

Meaningful descriptions of plant distributions in reservoirs are problematic because water levels vary through the course of a year (Brewer and Rorslett 1987). Water level fluctuations are a challenge to plant growth. A plant which begins the growing season at a depth of $3 \mathrm{~m}$ may be under $6 \mathrm{~m}$ of water after spring runoff fills the reservoir. Later in the summer, the same plant may be left at a depth of only $1 \mathrm{~m}$ as water is removed from the reservoir during summer drawdown. In reservoirs, where lake levels fluctuate substantially during the growing season, the physical environment is characterized by increased spatial and temporal heterogeneity. Disturbances associated with changing water levels include ice scour during winter drawdown, abrasion due to increased erosion along the lake shore and wave action. Recent work suggests that the magnitude and timing of water level fluctuations may be the most important factor regulating macrophyte community processes at shallower depths in reservoirs (Gasith and Gafny 1990; Brewer and Parker 1990; Rørslett 1984).

The status of the aquatic plant community in Jackson Lake was re-evaluated from June August, 1995. During this time, we compiled a species list and mapped the distribution of macrophyte species.

\section{PHOTIC ZONE}

Light penetration was measured with a Secchi disc. The bottom of the photic zone was calculated according to Cole (1979) as approximately 3 times the Secchi Depth. The approximate bottom limit of the photic zone ranged from about $4 \mathrm{~m}$ in the littoral zone near Lizard Creek, to more than $22 \mathrm{~m}$ off Deadman's point (Table 1). These values are greater than reported in previous years during August sampling periods.

\section{PLANT COMMUNITY COMPOSITION AND DISTRIBUTION}

In 1995, we collected 12 species of rooted aquatic macrophytes in Jackson Lake (Table 2). Species richness remains low, compared to the time immediately prior to repair of the dam in 1983/1984 when 22 species were collected. The number of species reported in 1995 is similar to species richness in 1990. 


\begin{tabular}{|c|c|c|c|c|c|c|c|c|}
\hline Site & $\begin{array}{r}\text { Aug } \\
1968\end{array}$ & $\begin{array}{c}\text { July } \\
1983\end{array}$ & $\begin{array}{r}\text { July } \\
1984\end{array}$ & $\begin{array}{r}\text { Aug } \\
1989\end{array}$ & $\begin{array}{r}\text { Aug } \\
1990\end{array}$ & $\begin{array}{l}\text { June } \\
1991\end{array}$ & $\begin{array}{l}\text { Aug } \\
1991\end{array}$ & $\begin{array}{r}\text { Aug } \\
1995\end{array}$ \\
\hline Lizard Creek & & 1.0 & & 0.8 & 0.8 & 0.5 & 1.8 & 1.3 \\
\hline Wilcox Point & & & & & 1.5 & 0.5 & 2.5 & 1.8 \\
\hline NW of Arizona Island & & 1.1 & & 1.4 & 1.5 & 0.5 & 5.8 & 1.5 \\
\hline North Sargent's Bay & & & & & 2.5 & 1.0 & 3.2 & 3.8 \\
\hline Sargent's Bay & & & & & & & 4.3 & \\
\hline UW-NPS Research Center & & 3.5 & 2.9 & 2.9 & 3.5 & 0.8 & 5.9 & 3.5 \\
\hline Half Moon Bay & & & & & 2.9 & 1.8 & 3.2 & \\
\hline NE of Elk Island & & 3.0 & 4.5 & & 5.6 & 0.8 & 6.5 & \\
\hline E of Waterfalls Canyon & 6.0 & 4.2 & & 3.8 & 6.0 & 0.9 & 4.5 & 5.1 \\
\hline North Moran Bay & & & & & & & & 4.8 \\
\hline Moran Bay & & & & & & & & 6.1 \\
\hline S of Pilgrim Creek & & & & 1.5 & 2.1 & 1.3 & 2.2 & \\
\hline W of Donoho Island & & & & & 6.0 & 1.8 & 7.0 & \\
\hline Bearpaw Bay & & & & & & & & 6.8 \\
\hline South Landing Bay & & 5.1 & 4.3 & 5.0 & 5.5 & 1.3 & 6.0 & 6.0 \\
\hline Deadman's Point & 6.0 & 5.0 & 4.8 & 4.1 & 6.5 & 1.0 & 5.5 & 7.5 \\
\hline $\mathrm{N}$ of Signal Boat Launch & & & & & & & & 6.0 \\
\hline Approximate Bottom & $10.0-$ & $3.0-$ & $8.7-$ & 2.4- & $2.4-$ & $1.5-$ & 5.4- & $3.9-$ \\
\hline Limit Photic Zone & 18.0 & 10.0 & 14.4 & 15.0 & 19.5 & 5.4 & 21.0 & 22.5 \\
\hline
\end{tabular}

Thirteen transects were sampled by SCUBA diving in 1995. Species diversity and abundance were low on all transects. Unlike previous years, Elodea canadensis was relatively uncommon in 1995. In most of the previous sampling periods, it was the dominant species in Jackson Lake. Other macrophyte species were locally abundant (e.g., Ranunculus sp., Potamogeton pectinatus). Peak cover was found at depths of 3-6 m. Potamogeton pectinatus was abundant in shallow habitats along the southeast shores of the lake. The distribution of Potamogeton richardsonii, $P . \quad$ pusillus and Myriophyllum sibiricum was patchy in both habitat types. Polygonum amphibium was also locally abundant along the far northwest and southeast shores of the lake. Most species present in 1995 were rarely collected. Exposed, steep shores remained mostly unvegetated in 1995.

\section{DISCUSSION}

Fluctuating water levels have the greatest effect in shallow, gently sloping habitats because more extensive areas are flooded and exposed with changes in the regulation scheme. Also along convoluted shorelines, changing water levels can substantially alter the size of bays. Such changes ultimately affect availability of habitat suitable for macrophyte growth in Jackson Lake.

Most species in Jackson Lake have patchy, disjunct distributions (e.g., Polygonum amphibium). Generally, plant cover on the lake bottom was low and species interference did not seem to be an important factor organizing this community. A similar conclusion has been drawn for plant communities in other regulated lakes characterized 
Table 2. Names of families and species collected from Jackson Lake, WY. ' + ' indicates species collected during the sampling year; '-' indicates not collected; '?' positive identification not possible based on plant material collected.

Species

\section{Years Collected}

\section{Alismatacea \\ Sagittaria cuneata Shel. \\ Callitrichaceae \\ Callitriche sp. \\ Ceratophyllaceae \\ Ceratophyllum demersum $\mathrm{L}$.}

Characeae

Chara sp.

Nitella sp.

Cyperaceae

Eleocharis acicularis (L.)R.\&S.

Fontinaliaceae

Fontinalis sp.

Haloragaceae

Myriophyllum excelbescens Fern.

Myriophyllum sibiricum Kom.

Hippuridaceae

Hippuris vulgaris $\mathrm{L}$.

Hydrocharitaceae

Elodea canadensis Michx.

Elodea nuttallii (Planch)St. John

Polygonaceae

Polygonum amphibium var.

stipulaceum Coleman

Potamogetonaceae

Potamogeton alpinus Balb.

Potamogeton filiformis Pers.

Potamogeton foliosus Raf.

Potamogeton gramineus $\mathrm{L}$.

Potamogeton pectinatus $\mathrm{L}$.

Potamogeton pusillus $\mathrm{L}$.

Potamogeton richardsonii (A.Benn) Rydberg

Ranunculaceae

Ranunculus aquatilis var. capillaceus(Thuill.)DC

Ranunculus reptans $\mathrm{L}$.

Scrophulariaceae

Limosella aquatica $\mathrm{L}$.

Sparganiaceae

Sparganium sp.

Zannichelliaceae

Zannichellia palustris $\mathrm{L}$.

Total species reported

\section{$\begin{array}{lllll}1968 & 1983 / 4 & 1989 & 1990 & 1995\end{array}$ \\ $\begin{array}{lllll}1968 & 1983 / 4 & 1989 & 1990 & 1995\end{array}$}

\begin{tabular}{|c|c|c|c|c|}
\hline - & + & - & + & - \\
\hline - & + & - & + & + \\
\hline+ & - & - & - & - \\
\hline+ & + & + & + & + \\
\hline - & + & - & + & - \\
\hline - & + & - & + & + \\
\hline- & + & + & - & + \\
\hline - & + & + & - & - \\
\hline+ & + & - & - & + \\
\hline+ & + & - & - & - \\
\hline+ & + & + & + & + \\
\hline- & + & - & - & - \\
\hline
\end{tabular}

\begin{tabular}{rrrrr}
- & + & + & + & + \\
- & + & - & - & + \\
+ & + & - & + & $?$ \\
- & + & $?$ & - & - \\
- & - & + & - & $?$ \\
- & + & + & + & + \\
- & + & $?$ & - & - \\
+ & + & - & - & + \\
+ & + & + & + & + \\
- & + & - & $?$ & + \\
& - & - & + & - \\
- & + & & & - \\
- & + & + & + & - \\
- & + & - & + & - \\
9 & 22 & 9 & 13 & 12 \\
\hline
\end{tabular}


by low plant densities and patchy plant cover (Rørslett 1987). Our data and observations suggest that the plant community in Jackson Lake is organized by physical processes acting along the vertical gradient (Brewer and Parker 1990). The upslope limits of macrophyte growth and persistence in Jackson Lake most likely are set by disturbances associated with changing water levels. Ice scour during winter drawdowns and spring break-up severely impacts overwintering tissues and may be responsible for damaging or removing plants on near shore lake margins (Rørslett 1984). Winter drawdowns in Jackson Lake are up to $1 \mathrm{~m}$. In addition to plants being stranded out of water, lowered water levels increase erosion and suspension of sediments (decreasing light penetration and suitable seed bed) and increase physical abrasion to plants from storm waves and boat wakes.

Downslope, it is possible that the bottom limit of macrophytes in Jackson Lake depends on light penetration and possibly temperature. Both temperature and light vary along the vertical gradient in Jackson Lake and neither factor was singled out in our analyses. Impoundment of natural lakes generally decreases light penetration (Rørslett, 1987). Light penetration eventually increases once small particles are eroded from shorelines. Reduced light penetration due to the suspension of fine particulates certainly may have limited the re-establishment of macrophytes in 1989, the first summer following the refilling of Jackson Lake. Moreover, Rorslett (1987) found that the water level regulation scheme may exacerbate macrophyte mortality by increasing the probability of low light conditions throughout the vertical gradient. This phenomenon remains important long after fine particulates are no longer present in the water column.

The extent of littoral habitat suitable for macrophyte growth in Jackson Lake depends on the nature of seasonal and longterm drawdowns (Brewer and Parker, 1990). Drawdown schedules and resulting fluctuating water levels may be selecting for a plant community characterized by low diversity and patchy distribution in Jackson Lake. High annual variations select for clonal species (e.g., Elodea canadensis, Ranunculus aquatilis and Myriophyllum sibiricum). Species propagating clonally have enhanced opportunities for dispersal under such a disturbance regime and are favored when drawdown occurs during the period of peak standing crop. Also as the plant community is shifted into deeper water, it is less accessible to many types of wildlife. Low annual variations are most favorable for plants that produce seeds annually and prefer shallower waters (e.g., Potamogeton species).

\section{ACKNOWLEDGMENTS}

This study was funded by the UW-NPS Research Center (1983-1985; 1995-1996) and by the U.S. Bureau of Reclamation with coordination through the Wyoming Game and Fish Department and the U.S. Fish and Wildlife Service (1989-1991). Melissa Brown, Michael Cooperman and Jerred Seveyka assisted with field work and/or data analysis in 1995.

\section{$\uparrow \quad$ Literature Cited}

Brewer, C. A. and M. Parker. 1990. Adaptations of macrophytes to life in moving water: upslope limits and mechanical properties of stems. Hydrobiol. 194:133-142.

Brewer, C. A. and B. Rørslett. 1987. Norwegian macrophyte models applied to an American reservoir. In $B$. Bretten and $O$. I. Ronning (eds.), Symposium in vegetation ecology at Kongsvold Biological Station in March 1987. Universitetet I Trondheim, Vitenskapsmuseet Rapport Botanisk Serie 1987 1:7-17.

Carpenter, S. R. and M. S. Adams. 1977. The macrophyte tissue nutrient pool of a hardwater eutrophic lake: implications for macrophyte harvesting. Aquat. Bot. 3:239-255.

Cole, G. A. 1979. Textbook of Limnology. C. V. Mosby, Co. Saint Louis, MO.

Duarte, C. M. and J. Kalff. 1986. Littoral slope as a predictor of maximum biomass of submerged macrophyte communities. Limnol. Oceanog. 30:1171-1187.

Gasith, A. and S. Gafny. 1990. Effect of water level fluctuation on the structure and function of the littoral zone. In M. M. Tilzer and C. Serruya (eds.), Large Lakes: Ecological Structure and Function. Springer-Verlag. Berlin. pp 156-171. 
Hayden, P.S. 1969. Jackson Lake Limnological Investigations. National Park Service Progress Report 1968-1969. Unpublished Report, GTNP.

Rorslett, B. 1984. Environmental factors and aquatic macrophyte response in regulated lakes a statistical approach. Aquat. Bot. 19:199-220.

Rorslett, B. 1987. Niche statistics of submerged macrophytes in Tyrifjord, a large oligotrophic Norwegian lake. Arch. Hydrobiol. 111:283308.

Spence, D. H. N. 1982. The zonation of plants in freshwater lakes. Adv. Ecol. Res. 12:37-135. 